\title{
Pseudomonas infection, allergy, and cystic fibrosis
}

\author{
R W PITCHER-WILMOTT, R J LEVINSKY, I GORDON, M W TURNER, AND D J MATTHEW \\ The Hospital for Sick Children, Great Ormond Street, and Department of Immunology, Institute of \\ Child Health, London
}

SUMmARY The clinical significance of the high prevalence of positive immediate skin tests in cystic fibrosis is unclear. Using analysis of variance, we have tested the hypothesis that patients with allergic cystic fibrosis have worse lung disease than non-allergic patients. Clinical data, skin prick tests, total or specific IgE antibody levels, chest radiographs, and pulmonary function tests were obtained in 104 cystic fibrosis patients. Patients with positive immediate skin reactions to at least one allergen were more likely to be persistently colonised by Pseudomonas aeruginosa than skin test negative patients. The skin test positive patients were also significantly older (mean difference $2 \cdot 15$ years). Analysis of variance showed that pseudomonas infection was the most significant factor contributing to lung damage and the effect of allergy was not significant. Similar longitudinal analysis of pulmonary function over 5 years and study of the hospital admission rate showed that the only statistically significant factor associated with deterioration was colonisation with $P$. aeruginosa.

A high prevalence of positive skin prick test reactions to common allergens, and particularly to Aspergillus fumigatus, has been reported in patients with cystic fibrosis (CF). ${ }^{1}$ The clinical significance of these observations is unclear but as some studies reported an association between lung disease and such positive skin reactions ${ }^{2-4}$ it was attractive to propose that they are associated with damaging allergic reactions in the lungs caused by type 1 reactions to inhaled allergens. Because the pulmonary symptoms of atopic allergy may respond to treatments such as inhaled sodium cromoglycate, steroid therapy, or hyposensitisation, it was important to investigate this relationship more closely. We have therefore tested the hypothesis that allergic CF patients have worse lung disease than non-allergic patients using several different criteria to diagnose allergy and analysis of variance to study the relevance of selected factors on cross-sectional data from $104 \mathrm{CF}$ children and longitudinal data from 54 of them.

\section{Subjects and methods}

\section{Subjects.}

\section{Cross-sectional study}

We studied 101 of 119 regular attenders aged at least 2 years at the CF clinic of The Hospital for Sick Children, Great Ormond Street, plus 3 further patients from an associated clinic. Informed consent by parents was obtained in each case. There were 104 patients in total ( 65 boys and 39 girls).

\section{Longitudinal study}

Data on 52 of the 104 patients were available from a cross-sectional study performed 5 years before. ${ }^{2}$ The chest radiographs were rescored (see below) and the other data, if available, were also used.

\section{Methods}

Symptoms of allergy and frequency of respiratory infection were recorded by interviewing the parents using a standard questionnaire and by referring to the case records. Our patients attend about every 2 months for review, and sputum or a cough swab is always cultured. The patient was defined as having chronic pulmonary colonisation with Pseudomonas aeruginosa (PA) or Staphylococcus aureus (SA) if there had been three consecutive isolations separated by intervals of at least one month. Each patient had anterior-posterior and lateral chest radiographs which were scored by the Chrispin and Norman method $^{5}$ by two observers acting jointly (I G and D J M). Fourteen prick tests were done on the skin of the flexor aspect of the forearms; the allergens were house-dust Dermatophagoides pteronyssinus, mixed feathers, dog hair, cat fur, Timothy grass pollen, rye grass pollen, whole cows' milk, whole egg, Aspergillus fumigatus, Aspergillus niger, Cladosporium herbarum, and Alternaria alternata (Bencard Allergy Service, Brentford, Middlesex, England). A formalin-saline control was always negative. The skin tests were measured after 15 minutes and they 
were considered positive if the weal exceeded $2 \mathrm{~mm}$ in diameter. If the patient was old enough to cooperate, peak flow rate (PEF) was measured by Wright's peak flow meter; vital capacity (VC), and forced expiratory flow at $25 \%$ vital capacity $\left(\mathrm{FEF}^{25}\right)$ were measured from a maximal expiratory flow volume curve, and thoracic gas volume (TGV) and residual volume to total lung capacity (RV/TLC) ratio by whole body plethysmography. All pulmonary function results (apart from RV/TLC ratio) were expressed as a percentage of the predicted normal value for height. ${ }^{6}$ Blood was taken if possible and serum was separated within 2 hours at room temperature and then stored in aliquots at $-70^{\circ} \mathrm{C}$. Total IgE was measured by a double antibody method $^{7}$ in 54 patients and IgE antibodies to $D$. pteronyssinus, Timothy grass pollen, and $A$. fumigatus in 73 patients using allergen-coated paper discs in a conventional radioallergosorbent test. ${ }^{8} \mathrm{~A}$ positive IgE antibody test was a ratio of ${ }^{125}$ I counts bound $>1.6$ compared with those bound with cord serum.

The statistical package for the social sciences of Northwestern University ${ }^{9}$ at the University of London Computer Centre was used to analyse the data. Multiway analysis of variance by the multiple regression approach was used to examine the contribution of metric and non-metric independent variables to variation in lung function. ${ }^{10}$ Insignificant covariates, interactions, and factors were removed singly and the analysis was repeated until a "parsimonious model' that included only statistically significant factors and covariates was produced.

\section{Results}

Cross-sectional analysis. Positive immediate skin reactions to at least one allergen were found in 58 $(56 \%)$ patients and these children had significantly worse lung function, higher chest radiograph scores, and greater number of hospital admissions (Table 1). However, they were also older than the skin test negative patients (Table 1) and were more likely to have chronic PA colonisation of the lungs (Table 1). There was no such association with chronic SA colonisation.

The relative frequencies of positive reactions to various antigens (Table 2) were similar to those reported before ${ }^{2}$ and the most prevalent reaction was to A. fumigatus which was positive in $35 \%$ of the CF children. Patients with chronic PA colonisation reacted more often to all antigens and significantly so for A. fumigatus, rye grass pollen, and dog hair. To examine whether this association was due to age, the prevalences of chronic PA colonisation, and those of the positive skin reactions most closely associated with such colonisation, were plotted
Table 1 Lung function, chest radiograph score, hospital admission rate, pseudomonas colonisation, and age in 104 children with cystic fibrosis according to skin test results

\begin{tabular}{|c|c|c|c|}
\hline & \multicolumn{2}{|l|}{ Skin test } & \multirow[t]{2}{*}{$P$ value } \\
\hline & $\begin{array}{l}\text { Negative } \\
(n=46)\end{array}$ & $\begin{array}{l}\text { Positive to } \\
\text { any antigen } \\
(n=58)\end{array}$ & \\
\hline $\begin{array}{l}\text { FEF } 25(\% \text { predicted }) \\
(\text { mean } \pm \text { SE) } \\
\text { RV } / \text { TLC }(\%) \\
(\text { mean } \pm \text { SE) }\end{array}$ & $\begin{array}{l}65 \pm 2 \\
40 \pm 2\end{array}$ & $\begin{array}{l}44 \pm 4 \\
47 \pm 2\end{array}$ & $\begin{array}{l}<0.01 \dagger \\
<0.05 \dagger\end{array}$ \\
\hline $\begin{array}{l}\text { Chest radiograph score } \\
\text { (mean } \pm \mathrm{SE}) \\
\text { Median }\end{array}$ & $\begin{array}{l}6 \cdot 0 \pm 0 \cdot 6 \\
5 \cdot 4\end{array}$ & $\begin{array}{l}10 \cdot 0 \pm 0.6 \\
9.6\end{array}$ & $<0.0001 \ddagger$ \\
\hline $\begin{array}{l}\text { Admissions per year } \\
\text { (mean } \pm \text { SE) } \\
\text { Median }\end{array}$ & $\begin{array}{l}0.17 \pm 0.08 \\
0.08\end{array}$ & $\begin{array}{l}0.91 \\
0.23\end{array}$ & $<0.02 \ddagger$ \\
\hline $\begin{array}{l}\text { Chronic PA colonisation } \\
(\%) \\
\text { Age (years) (mean } \pm \text { SE) }\end{array}$ & $\begin{array}{l}17 \\
8 \cdot 25 \pm 0.62\end{array}$ & $\begin{array}{l}48 \\
10 \cdot 4 \pm 0.47\end{array}$ & $\begin{array}{l}<0.005 \S \\
<0.01 \dagger\end{array}$ \\
\hline
\end{tabular}

$\dagger$ By Student's $t$ test, $\ddagger$ by Mann-Whitney $U$ test, $\S$ by $\chi^{2}$ test.

Table 2 Frequency (\%) of positive skin tests in 104 patients with cystic fibrosis

\begin{tabular}{|c|c|c|c|c|}
\hline & \multirow[t]{2}{*}{ All cases } & \multicolumn{2}{|c|}{ Pseudomonas } & \multirow[t]{2}{*}{$P$ value $\ddagger$} \\
\hline & & $\begin{array}{l}\text { Negative } \\
\text { cases }\end{array}$ & $\begin{array}{l}\text { Positive } \\
\text { cases } \dagger\end{array}$ & \\
\hline A. fumigatus & 35 & 25 & 53 & $<0.01$ \\
\hline Rye grass pollen & 30 & 22 & 44 & $<0.05$ \\
\hline $\begin{array}{l}\text { Timothy grass } \\
\text { pollen }\end{array}$ & 26 & 21 & 36 & NS \\
\hline $\begin{array}{l}\text { House dust } \\
\text { extract }\end{array}$ & 24 & 21 & 31 & NS \\
\hline D. pteronyssinus & 16 & 12 & 25 & NS \\
\hline Cat fur & 15 & 12 & 22 & NS \\
\hline A. alternata & 15 & 12 & 22 & NS \\
\hline Whole milk & 14 & 10 & 19 & NS \\
\hline A. niger & 11 & 7 & 17 & NS \\
\hline C. herbarum & 9 & 7 & 11 & NS \\
\hline Feathers & 8 & 4 & 14 & NS \\
\hline Dog hair & 8 & 3 & 17 & $<0.05$ \\
\hline Whole egg & 8 & 7 & 8 & NS \\
\hline
\end{tabular}

† Pseudomonas was grown consistently from the sputum of $35 \%$ ( $\mathrm{n}=36$ ) of patients. $\ddagger \mathrm{By} \chi^{2}$ on absolute numbers.

against age (Figure). The results showed that chronic PA infection and positive skin tests were closely associated independently of age and a biphasic distribution was noted with the first peak in the age group 8 to 10 years (but no patient ever lost chronic PA colonisation). PA colonised patients also had significantly worse lung function than CF patients without such infection (Table 3). We therefore undertook analysis of variance of factors which were possibly relevant to lung disease in CF: positive skin prick test reactions, chronic SA colonisation, and chronic PA colonisation. Covariates used were age and duration of respiratory symptoms. The contribution of these variables to 


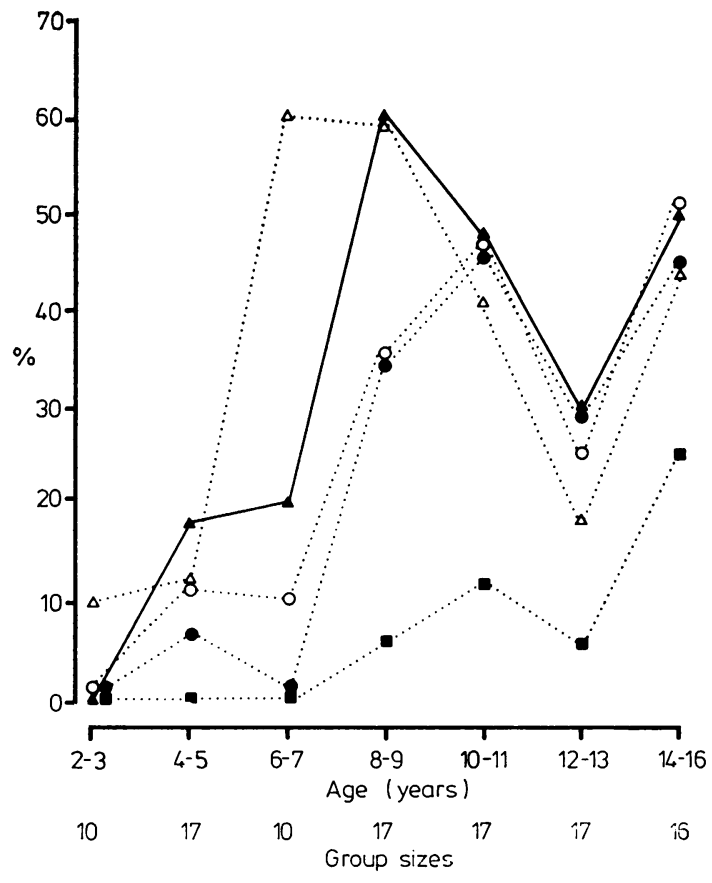

Figure Prevalences of pseudomonas colonisation (solid line) and positive skin reactions (broken lines) by age in 104 patients with cystic fibrosis.

$\triangle$ Aspergillus fumigatus, O rye grass pollen, - Timothy grass pollen, $\square$ dog hair.

poor lung function was analysed by a process of stepwise elimination. Because it has been proposed that allergy to $A$. fumigatus is the most significant correlate of poor lung function ${ }^{3}$ the skin test results were entered as four groups: (1) patients sensitive to one of the 4 moulds used, (2) patients sensitive to one of the other allergens, (3) patients sensitive to one of the moulds and one of the other allergens, (4) patients who were sensitive to none of the
Table 3 Lung function, chest radiograph score, and hospital admission rate in $36 \mathrm{CF}$ patients chronically colonised with $\mathrm{P}$. aeruginosa $(C F+P A)$ and $68 C F$ patients without such infection $(C F-P A)$

\begin{tabular}{|c|c|c|c|}
\hline & $C F-P A$ & $C F+P A$ & $P$ value \\
\hline $\begin{array}{l}\text { VC (\% predicted }) \\
\quad(\text { mean } \pm \text { SE) }\end{array}$ & $85 \pm 2$ & $68 \pm 3$ & $<0.001 \dagger$ \\
\hline $\begin{array}{l}\text { TGV ( } \% \text { predicted }) \\
\text { (mean } \pm \text { SE) } \\
\text { PEF }(\% \text { predicted })\end{array}$ & $128 \pm 3$ & $154 \pm 7$ & $<0.005 \dagger$ \\
\hline 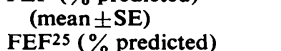 & $97 \pm 2$ & $79 \pm 4$ & $<0.001 \dagger$ \\
\hline $\begin{array}{l}(\text { mean } \pm \text { SE) } \\
\operatorname{RV} / \mathrm{TLC}(\%)\end{array}$ & $68 \pm 5$ & $32 \pm 4$ & $<0.001 \dagger$ \\
\hline $\begin{array}{l}\text { (mean } \pm \text { SE) } \\
\text { Chest radiograph score }\end{array}$ & $39 \pm 2$ & $53 \pm 2$ & $<0.001 \dagger$ \\
\hline $\begin{array}{c}(\text { mean } \pm S E) \\
\text { Median }\end{array}$ & $\begin{array}{l}6 \cdot 3 \pm 0 \cdot 4 \\
6 \cdot 1\end{array}$ & $\begin{array}{l}12 \cdot 1 \pm 0.9 \\
11 \cdot 3\end{array}$ & $<0.0001 \ddagger$ \\
\hline $\begin{array}{l}\text { Hospital admissions a year } \\
\text { (mean } \pm \text { SE) } \\
\quad \text { Median }\end{array}$ & $\begin{array}{l}0.06 \pm 0.03 \\
0.03\end{array}$ & $\begin{array}{ll}3 & 1.57 \pm 0.31 \\
0.81\end{array}$ & $<0.001 \ddagger$ \\
\hline
\end{tabular}

$\dagger$ By Student's $t$ test, $\ddagger$ by Mann-Whitney U test.

allergens. The analysis showed that the factor most significantly associated with severity of lung disease was chronic PA colonisation (Table 4). Positive skin test reactions were only weakly (and insignificantly) associated with poor lung function in this analysis. SA colonisation was also insignificant and the only two significant parameters apart from chronic PA colonisation were age (covariate with $\left.\mathrm{FEF}^{25}, \quad \mathrm{P}<0.001\right)$ and duration of respiratory symptoms (covariate with PEF, $\mathrm{P}<0.05$ ). Hospital admission rate and chest radiograph score were not analysed in this way because they are not normally distributed parametric variables. A similar analysis of variance was performed with other factors that might relate to lung function-namely IgE concentration, positive IgE antibodies (radioallergosorbent test), and history of asthma or hay fever (23 patients) -while controlling for chronic PA colonisation and the significant covariates already described. None of these factors was significantly correlated with poor lung function (Table 4).

Table 4 Associations (variance ratios $-F$ ) of selected independent variables on lung function in analysis of variance $\dagger$

\begin{tabular}{|c|c|c|c|c|c|c|c|c|}
\hline & \multicolumn{8}{|c|}{ Independent variables } \\
\hline & $\begin{array}{l}\text { Pseudomonas } \\
\text { colonisation }\end{array}$ & $\begin{array}{l}\text { Staphylococcal } \\
\text { colonisation }\end{array}$ & Age & $\begin{array}{l}\text { Duration of } \\
\text { respiratory } \\
\text { symptoms }\end{array}$ & $\begin{array}{l}\text { Skin test } \\
\text { positivity }\end{array}$ & $\underset{\operatorname{Ig} E}{\log 10}$ & $\begin{array}{l}\text { Positive } \\
R A S T\end{array}$ & $\begin{array}{l}\text { Respiratory } \\
\text { allergic disease }\end{array}$ \\
\hline $\begin{array}{l}\text { FEF25 } \\
\text { RV/TLC } \\
\text { TGV } \\
\text { VC } \\
\text { PEF }\end{array}$ & $\begin{array}{l}29 \cdot 3^{* * *} \\
22 \cdot 9^{* * *} \\
13 \cdot 0^{* * *} \\
19 \cdot 3^{* * *} \\
11 \cdot 3^{* * *}\end{array}$ & $\begin{array}{l}1 \cdot 54 \\
0 \cdot 19 \\
2 \cdot 53 \\
0.63 \\
1 \cdot 00\end{array}$ & $\begin{array}{l}7.22^{* *} \\
0.02 \\
1.88 \\
1.74 \\
0.01\end{array}$ & $\begin{array}{l}0.77 \\
0.61 \\
0.20 \\
1 \cdot 19 \\
5 \cdot 03^{*}\end{array}$ & $\begin{array}{l}1.34 \\
0.52 \\
1.92 \\
0.80 \\
0.37\end{array}$ & $\begin{array}{l}0.11 \\
0.82 \\
0.39 \\
0.00 \\
0.45\end{array}$ & $\begin{array}{l}0.63 \\
2.21 \\
3.67 \\
0.46 \\
0.16\end{array}$ & $\begin{array}{l}1.03 \\
0.05 \\
0.17 \\
0.59 \\
0.64\end{array}$ \\
\hline
\end{tabular}

$* * \mathrm{P}<0.001, \quad * * \mathrm{P}<0.01, * \mathrm{P}<0.05$.

+ Values for PA and SA colonisation, age, duration of respiratory symptoms, and skin tests were obtained during analysis of variance and sequential elimination. Those for FEF 25 and PEF are corrected for significant independent variables. Values for serum IgE (logged to normalise) positive RAST and allergic disease are those calculated when these variables were added to the significant parsimonious effects model (see text). RAST = radioallergosorbent test. 
Table 5 Variance ratios $(F)$ in analysis of variance on changes in severity in patients with cystic fibrosis during 5 yearst

\begin{tabular}{|c|c|c|c|c|}
\hline \multirow[b]{2}{*}{ Dependent variables } & \multicolumn{4}{|l|}{ Independent variables } \\
\hline & $\begin{array}{l}\text { Change in pseudomonas } \\
\text { colonisation }\end{array}$ & $\begin{array}{l}\text { Change in staphylococcal } \\
\text { colonisation }\end{array}$ & $\begin{array}{l}\text { Change in skin test } \\
\text { reactivity }\end{array}$ & Age \\
\hline $\begin{array}{l}\text { Change in chest radiograph score } \\
\text { Change in hospital admission rate } \\
\text { Change in VC } \\
\text { Change in PEF }\end{array}$ & $\begin{array}{l}5 \cdot 55^{* *} \\
7 \cdot 20^{* *} \\
3 \cdot 66^{* *} \\
3 \cdot 28^{* *}\end{array}$ & $\begin{array}{l}0.38 \\
0.37 \\
0.36 \\
0.07\end{array}$ & $\begin{array}{l}1 \cdot 61 \\
1 \cdot 38 \\
1 \cdot 11 \\
0 \cdot 56\end{array}$ & $\begin{array}{l}0.49 \\
1 \cdot 01 \\
0 \cdot 39 \\
1 \cdot 09\end{array}$ \\
\hline
\end{tabular}

$* \mathbf{P}<0.01$.

$\dagger$ For significant independent variables final $F$ values are shown. Other $F$ values are those during sequential removal in stepwise analysis.

Longitudinal analysis. The changes in chest radiograph score, hospital admission rate, PEF, and VC over 5 years in the $54 \mathrm{CF}$ children followed up were significantly related to PA colonisation but not to SA colonisation, acquisition of positive skin tests, or age when PA colonisation was controlled for in analysis of variance (Table 5). Data on changes in TGV, RV/TLC, or FEF ${ }^{25}$ were too few for analysis.

\section{Discussion}

These results show that, of the factors examined, chronic PA colonisation was most closely associated with pulmonary disease in CF. Although positive skin test reactions were significantly associated with lung disease, this association became insignificant when the data were adjusted for the effect of PA. This suggested that the apparent effect of skin test reactions in the raw data and in other studies ${ }^{2-4}$ resulted from their significant association with chronic PA infection. The prevalence of $35 \%$ for chronic PA colonisation is lower than that in some other centres ${ }^{11}$ and allowed the effect of PA to be determined in analysis of variance. We have no explanation for this low prevalence although our avoidance of prolonged anti-staphylococcal treatment may be relevant.

The analysis of cross-sectional and longitudinal data strengthens the view that the association of chronic PA colonisation with poor lung function is probably causative. PA is a well recognised pathogen which could cause lung damage by proteases, exotoxins, or other mediators of inflammation. ${ }^{12}$ It is also possible that the ability of PA to evoke an IgE response in $\mathrm{CF}^{13}$ could be important.

There are several possible mechanisms for the role of PA colonisation in the development of pulmonary sensitisation to inhaled antigens. Firstly, entry of antigens through damaged bronchial epithelium could be increased, with resulting greater exposure of the immune system to the antigen. Secondly, increased gas trapping, thicker secretions, and slower mucociliary clearance might prolong retention of antigens. Thirdly, the viscid alginate produced by the mucoid strains of PA found in $\mathrm{CF}^{11}$ might trap antigens in the airways and alveoli. Finally, PA may have an adjuvant effect with inhaled antigens.

The analysis of serum IgE and IgE antibody tests confirmed the lack of significant association between allergy and lung disease. There have also been reports of milder pulmonary disease in CF patients with asthma or hay fever based on analysis of clinical scores; $\mathbf{;}^{14}$ our data do not confirm this either.

The $35 \%$ frequency of response to $A$. fumigatus by skin testing was similar to that in our earlier study, ${ }^{2}$ in other CF centres in Britain and the USA, ${ }^{\mathbf{1 3 4}}$ and in a population of British asthmatic schoolchildren tested with a mould extract, ${ }^{15}$ whereas none of 51 age-matched controls reacted in the last mentioned study. The responses to the other antigen were similar in frequency to those seen in a population sample of children. ${ }^{16}$ The high prevalence of sensitisation to $A$. fumigatus in CF patients is unexplained. Although allergic bronchopulmonary aspergillosis has been described in a significant proportion of patients from one centre, ${ }^{4}$ none of our series fulfilled the accepted criteria. ${ }^{17}$ This discrepancy may be the effect of differences in climate and housing; nevertheless, allergic broncnopulmonary aspergillosis does not account for the high prevalence of $\boldsymbol{A}$. fumigatus sensitisation in the patients we studied. Another possible explanation would be cross-reactivity with PA, but there was no evidence of this in a study of CF antibody to A. fumigatus using a sensitive primary binding assay. ${ }^{18}$ The possibility of selective filtration by the lungs according to particle size has been considered ${ }^{19}$ but this hypothesis is not resolved by our data as Alternaria sp. and Cladosporium sp. have large spores which should be trapped in the nose and main bronchi. It would be interesting to find out if patients with CF have a high prevalence of skin reactions to other moulds which have the same spore size as $A$. fumigatus and which are equally ubiquitous.

The prevalence of PA colonisation could be placed in the age groups 10 to 12 years and 12 to 14 years although none of our patients who were chronically colonised with PA ever eliminated it. This suggests 
that early acquisition of PA is associated with early death; this is the subject of other studies in progress.

We conclude that pseudomonas infection, rather than allergy, is the major determinant of severity of pulmonary disease in CF. While acknowledging the difficulty of eliminating this infection, it is hoped that improved therapeutic methods-for example by blocking alginate synthesis by mucoid strainswill lead to an improved prognosis. It seems probable that, unless patients have coexistent asthma, treatments such as hyposensitisation, inhaled steroids, or inhaled cromoglycate will have no major benefit.

We thank Mrs Shaku Odjavji for the total IgE and specific IgE antibody estimations; Dr J O Warner for access to earlier skin test data; Dr J Lobb of the Public Health Reference Laboratory, Colindale, and Dr M Preece for statistical advice; Bencard Allergy Service for supplying the skin testing materials and $A$. fumigatus sero-diagnostic antigen.

R W P-W was supported by the Cystic Fibrosis Research Trust, Grant No 140.

\section{References}

1 Warren C P W, Tai E, Batten J C, Hutchcroft B J, Pepys J. Cystic fibrosis-immunological reactions to A. fumigatus and common allergens. Clin Allergy 1975; 1: $1-12$.

2 Warner J O, Taylor B W, Norman A P, Soothill J F. Association of cystic fibrosis with allergy. Arch Dis Child 1976; 51 : 507-11.

3 Silverman M, Hobbs F D R, Gordon I R S, Carswell F. Cystic fibrosis, atopy, and airways lability. Arch Dis Child 1978; 53: 873-7.

4 Nelson L A, Callerame M L, Schwartz R H. Aspergillosis and atopy in cystic fibrosis. Am Rev Respir Dis 1979; 120: $863-73$.

5 Chrispin A R, Norman A P. The systematic evaluation of the chest radiograph in cystic fibrosis. Pediatr Radiol $1974 ; 2$ : 101-6.
6 Cogswell J J, Hull D, Milner A D, Norman A P, Taylor B. Lung function in childhood. $\mathrm{Br} J$ Dis Chest 1975; 69: 40-50, 118-24, 177-87.

7 Nye L, Merrett T G, Landon J, White R J. A detailed investigation of circulating IgE levels in a normal population. Clin Allergy 1975; 1: 13-24.

8 Ceska M, Eriksson R, Varga J. Radioimmunosorbent assay of allergens. J Allergy Clin Immunol 1972; 49: 1-9.

9 Nie N H, Hadlai Hull C, Jenkins J G, Steinbrenner K, Bert D H. Statistical package for the social sciences, second edition. New York: McGraw-Hill, 1975.

10 Armitage P. Statistical methods in medical research. Oxford: Blackwell, 1971.

11 Doggett R G, Harrison G M, Stillwell R N, Wallis E S. An atypical Pseudomonas aeruginosa associated with cystic fibrosis of the pancreas. J Pediatr 1966; 68: 215-21.

12 Marks M I. The pathogenesis and treatment of pulmonary infections in patients with cystic fibrosis. J Pediatr 1981; 98: 173-9.

13 Moss R B, Hsu Y-P, Lewiston N J. ${ }^{125}$ I-Clq-binding and specific antibodies as indicators of pulmonary disease activity in cystic fibrosis. $J$ Pediatr 1981 ; 99: 215-22.

14 Rachelefsky G S, Osher A, Dooley R E, Ank B, Stiehm E R. Co-existent respiratory allergy and cystic fibrosis. Am J Dis Child 1974; 128: 355-9.

15 Sarsfield J K. Role of house-dust mites in childhood asthma. Arch Dis Child 1974; 49: 711-5.

16 Barbee R A, Lebowitz M D, Thompson H C, Burrows B. Immediate skin test reactivity in a general population sample. Ann Intern Med 1976; 84: 129-33.

17 Turner-Warwick M. Immunology of the lower respiratory tract. In: Brostoff J, ed. Clinical immunology. Allergy in paediatric medicine. Proceedings of the First Unigate Paediatric Workshop, London, June 1973. Oxford: Blackwell, 1973: 163-76.

18 Bardana E J, Jr, Sobti K L, Cianciulli F D, Noonan M J. Aspergillus antibody in patients with cystic fibrosis. Am J Dis Child 1975; 129: 1164-7.

19 Austwick P K C. The role of spores in the allergies and mycoses of man and animals. In: Madelin M F, ed. The fungus spore. Proceedings of the Eighteenth Symposium of the Colston Research Society. London: Butterworth, 1966: 321-38.

Correspondence to Dr R J Levinsky, Department of Immunology, Institute of Child Health, Guilford Street, London WC1N 1EH.

Received 5 January 1982 